OPEN ACCESS

Edited by:

Michael Heinrich,

UCL School of Pharmacy,

United Kingdom

Reviewed by:

Ahmet Uysal,

Selçuk University, Turkey

Concepción Obon,

Universidad Miguel Hernández de

Elche, Spain

Evangelos Axiotis,

National and Kapodistrian University

of Athens, Greece

*Correspondence:

Marcello Locatelli

m.locatelli@unich.it

Bulent Kirkan

bulentkirkan32@gmail.com

Specialty section:

This article was submitted to

Ethnopharmacology,

a section of the journal

Frontiers in Pharmacology

Received: 05 July 2018

Accepted: 16 December 2019

Published: 14 February 2020

Citation:

Sarikurkcu C, Locatelli M, Mocan A,

Zengin $G$ and Kirkan B (2020) Phenolic Profile and Bioactivities of Sideritis perfoliata L.: The Plant, Its

Most Active Extract, and Its

Broad Biological Properties.

Front. Pharmacol. 10:1642.

doi: 10.3389/fphar.2019.01642

\section{Phenolic Profile and Bioactivities of Sideritis perfoliata L.: The Plant, Its Most Active Extract, and Its Broad Biological Properties}

\author{
Cengiz Sarikurkcu ${ }^{1}$, Marcello Locatelli ${ }^{2 *}$, Andrei Mocan ${ }^{3}$, Gokhan Zengin ${ }^{4}$ \\ and Bulent Kirkan ${ }^{5 *}$ \\ ${ }^{1}$ Department of Analytical Chemistry, Afyonkarahisar University of Health Sciences, Faculty of Pharmacy, Afyonkarahisar, \\ Turkey, ${ }^{2}$ Department of Pharmacy, D'Annunzio University of Chieti-Pescara, Chieti, Italy, ${ }^{3}$ Department of Pharmaceutical \\ Botany, Iuliu Hatjieganu University of Medicine and Pharmacy, Cluj-Napoca, Romania, ${ }^{4}$ Department of Biology, Selcuk \\ University, Science Faculty, Konya, Turkey, ${ }^{5}$ Water Institute, Süleyman Demirel University, Isparta, Turkey
}

Sideritis, also named "ironwort," "mountain tea," or "shepherd's tea," is a genus of flowering plants used as herbal medicine in traditional Mediterranean-area medicine systems, and these plants are generally consumed as a herbal tea. Its use as herbal tea and in traditional herbal medicine is quite popular. There are currently few studies on Sideritis perfoliata L., and only one reports the use of a liquid chromatography coupled to diode array detection and electrospray ionization tandem mass spectrometry (LC-DADESI-MS ${ }^{n}$ ) profile and the content of phenolic compounds without considering a possible correlation with its biological activities. This paper aims to investigate the antioxidant activities by means of several different biological/biochemical assays (radical scavenging, reducing power, ferrous ion chelating, and total antioxidant by phosphomolybdenum and $\beta$-carotene bleaching methods) as well as analyze the enzyme inhibitory activities (against AChE (acetylcholinesterase), BChE (butyrylcholinesterase), tyrosinase, $\alpha$-glucosidase, and $\alpha$-amylase) as well as the total phenolics, flavonoids, and condensed tannins. The reported results on Sideritis perfoliata highlighted that methanol and water extracts generally showed higher radical scavenging and reducing power activities. A similar trend could be observed for phosphomolybdenum and ferrous ion chelating activities. Methanol extracts showed lower activity only for the $\beta$-carotene bleaching assay.

Keywords: Sideritis perfoliata, LC-ESI-MS/MS, phenolic profile, enzyme inhibitory activities, antioxidant activities

\section{INTRODUCTION}

In recent years, natural products have gained momentum in the designing of novel pharmaceutical products and herbal drugs. Many natural products or herbal preparations are currently being used for the treatment of several ailments both in modern or traditional medicine (Shen, 2015; Boy et al., 2018).

Sideritis (Lamiaceae), also named "ironwort," "mountain tea," or "shepherd's tea," is a genus of flowering plants used as herbal medicine; it has several traditional uses, and it is generally consumed 
as herbal tea. The genus contains about 150 species, and these are distributed in the temperate climate of the Northern hemisphere (González-Burgos et al., 2011). The plants appear as short $(8-50 \mathrm{~cm}$ ) xerophytic subshrubs or herbs, annual or perennial, that grow at high altitudes (generally over $1000 \mathrm{~m}$ ) with little or no soil and often on the surface of rocks. This genus is widely distributed in several Mediterranean regions, in the Balkans, in the Iberian Peninsula, in the Macaronesia, in Central Europe, and in temperate regions of Asia (Barber, 2000; Lindqvist and Albert, 2002).

Its use as herbal tea and in traditional herbal medicine is popular in Greece, Turkey, Albania, Kosovo, Bulgaria, and the Republic of Macedonia. Particularly, Sideritis scardica Griseb., used as herbal tea, is frequently prepared by decoction or infusion of the stems, leaves, and flowers (aerial parts). This herbal medicine is used traditionally to aid digestion, enforce the immune system, and reduce the symptoms of various illnesses. Several studies have reported a possible correlation with a positive effect of this plant on many common ailments (González-Burgos et al., 2011; Tadić et al., 2012), particularly with related to its anti-microbial, anti-inflammatory, and antioxidant activities. The main active compounds present in this genus are diterpenoids and flavonoids (Villar et al., 1986).

S. perfoliata is perennial with simple or branched stems and grows to height of $60 \mathrm{~cm}$. Leaves are ovate, oblong, or oblonglanceolate. Flowers are yellow in color. The species is mainly distributed to the east and Mediterranean region of Turkey (Davis, 1982). S. perfoliata is of great interest in term of traditional uses as it has antimicrobial, analgesic, stomachic, and carminative properties (Gonzalez-Burgos et al., 2011; Lall et al., 2019). There are only a few papers written on Sideritis perfoliata L. (Loizzo et al., 2007; Charami et al., 2008; Loizzo et al., 2008; Petreska et al., 2011; Çelik et al., 2016), and only one reports its LC-DAD-ESI-MS ${ }^{\mathrm{n}}$ profile and content of phenolic compounds (3 hydroxycinnamic acid derivatives, 8 phenylethanoid glycosides, and 24 flavonoid glycosides) (Petreska et al., 2011). The other works report the biological activities merely against angiotensin converting enzyme (ACE), digestive enzymes related to diabetes (Loizzo et al., 2008), and the antioxidant and antiinflammatory (Charami et al., 2008) as well as cytotoxic activity of essential oils (Loizzo et al., 2007). In addition, S. perfoliata is widely used in traditional medicine as an anti-inflammatory, antiulcer, vasoprotector, and for treatment against colds, coughs, and the flu.

Following our previous research on plant materials used as tea (Melucci et al., 2013), foods (Sobolev et al., 2018; Di Sotto et al., 2018), food supplements (Locatelli et al., 2017), traditional herbal medicine (Uysal et al., 2017), and their content of toxic/heavy metals (Locatelli et al., 2014; Melucci et al., 2018), we highlight and complete here the phytochemical information on this traditionally used medicinal plant.

In current research, we aimed to determine the antioxidant capacity of three extracts (ethyl acetate, methanol, and water) from Sideritis perfoliata by means of several chemical assays (radical scavenging, reducing power, ferrous ion chelating, and total antioxidant by phosphomolybdenum and $\beta$-carotene bleaching methods) and to explain their inhibitory effects against $\mathrm{AChE}, \mathrm{BchE}$, tyrosinase, $\alpha$-glucosidase, and $\alpha$-amylase. In addition, the chemical characterization for these extracts were performed by spectrophotometric and chromatographic methods.

\section{MATERIALS AND METHODS}

\section{Chemicals}

Gallic acid, (+)-catechin, pyrocatechol, chlorogenic acid, 2,5dihydroxybenzoic acid, 4-hydroxybenzoic acid, (-)-epicatechin, caffeic acid, syringic acid, vanillin, taxifolin, sinapic acid, $p$ coumaric acid, ferulic acid, rosmarinic acid, 2-hydroxycinnamic acid, pinoresinol, quercetin, luteolin, and apigenin were purchased from Sigma-Aldrich (St. Louis, MO, USA). Vanillic acid, 3hydroxybenzoic acid, 3,4-dihydroxyphenylacetic acid, apigenin 7 glucoside, luteolin 7-glucoside, hesperidin, eriodictyol, and kaempferol were obtained from Fluka (St. Louis, MO, USA). Finally, verbascoside, protocatechuic acid, and hyperoside were purchased from HWI Analytik (Ruelzheim, Germany). Methanol and formic acid of HPLC grade were purchased from SigmaAldrich (St. Louis, MO, USA) and Merck (Darmstadt, Germany), respectively. Ultra-pure water $(18 \mathrm{~m} \Omega)$ was obtained from a Milli$\mathrm{Q}$ water purification system (Millipore Co., Ltd.)

Ethyl acetate and methanol were obtained from Carlo Erba Reagents (Milan, Italy). Ultra-pure water was obtained using a Millipore Milli-Q Plus water treatment system (Millipore Bedford Corp., Bedford, MA). All chemicals were of analytical grade.

\section{Plant Material}

Aerial parts of Sideritis perfoliata L. were purchased from the local market in Isparta Province in the Mediterranean Region of Turkey on 15 January 2014 (1020 m, 37 45'52.90” N 30 33' $16.02^{\prime \prime E}$ ). The plant was authenticated by Dr. Olcay Ceylan and deposited at the herbarium of the Department of Biology, Mugla Sitki Kocman University (Mugla-Turkey) under the accession no. OC.3003.

\section{Preparation of the Extracts}

Air-dried aerial parts of $S$. perfoliata were individually extracted by using a Soxhlet extractor for $5 \mathrm{~h}$ with $250 \mathrm{~mL}$ of ethyl acetate, methanol, or water as previously described by Sarikurkcu et al. (2014). All extracts were stored at $+4^{\circ} \mathrm{C}$ until the analyses, and all analysis were completed in 10 days.

\section{Total Bioactive Components}

Total phenolic, flavonoid, and condensed tannin content was determined by employing the methods given in the literature (Zengin et al., 2014). For total phenolic content, the sample solution $(0.25 \mathrm{~mL})$ was mixed with diluted Folin-Ciocalteu reagent $(1 \mathrm{~mL}, 1: 9)$ and shaken vigorously. After $3 \mathrm{~min}$, a $\mathrm{Na}_{2} \mathrm{CO}_{3}$ solution $(0.75 \mathrm{~mL}, 1 \%)$ was added, and the sample absorbance was read at $760 \mathrm{~nm}$ after $2 \mathrm{~h}$ incubation at room temperature. Total phenolic content was expressed as equivalents of gallic acid. 
For total flavonoid content, the sample solution $(1 \mathrm{~mL})$ was mixed with the same volume of aluminium trichloride (2\%) in methanol. Similarly, a blank was prepared by adding the sample solution $(1 \mathrm{~mL})$ to methanol $(1 \mathrm{~mL})$ without $\mathrm{AlCl}_{3}$. The sample and blank absorbance were read at $415 \mathrm{~nm}$ after $10 \mathrm{~min}$ incubation at room temperature. Absorbance of the blank was subtracted from that of the sample. Total flavonoid content was expressed as equivalents of quercetin.

For total condensed tannin content, sample solution $(0.5 \mathrm{~mL})$, was mixed with a vanillin reagent $\left[1.5 \mathrm{~mL}, 1 \%\right.$ in $7 \mathrm{M} \mathrm{H}_{2} \mathrm{SO}_{4}$ (96\%)] in an ice bath and then mixed well. Similarly, a blank was prepared by adding the sample solution $(0.5 \mathrm{~mL})$ to $7 \mathrm{M} \mathrm{H}_{2} \mathrm{SO}_{4}$ $(1.5 \mathrm{~mL})$. The sample and blank absorbances were read at 500 $\mathrm{nm}$ after a $15 \mathrm{~min}$ incubation at room temperature. The absorbance of the blank was subtracted from that of the sample. The total condensed tannin content was expressed as equivalents of $(+)$-catechin.

\section{Liquid Chromatography-Electrospray Ionization-Tandem Mass Spectrometry (LC-ESI-MS/MS) Analysis}

An Agilent Technologies 1260 Infinity liquid chromatography system hyphenated to a 6420 Triple Quad mass spectrometer was used for quantitative analyses. Chromatographic separation was carried out on a Poroshell 120 EC-C18 (100 mm $\times 4.6 \mathrm{~mm}$ I.D., $2.7 \mu \mathrm{m})$ column. Three mobile phases were tested to obtain a complete resolution of all isomers and the highest sensitivity for all target compounds, namely (i) $0.1 \%$ formic acid/methanol, (ii) $5 \mathrm{mM}$ ammonium acetate/acetonitrile with $0.1 \%$ acetic acid, and (iii) $10 \mathrm{mM}$ ammonium formate with $0.1 \%$ formic acid/ acetonitrile with $0.1 \%$ formic acid. The first mobile phase configuration ( $0.1 \%$ formic acid/methanol) was selected on the base of the better chromatographic resolution of isomeric compounds. On the other hand, the selected mobile phase configuration also provided higher sensitivity for most of the phenolic compounds.

As a result, the mobile phase was made up from solvent $\mathrm{A}$ $(0.1 \%, v / v$ formic acid solution) and solvent B (methanol). The gradient profile was set: $0.0 \min 2 \% \mathrm{~B}$ eluent, $3.0 \min 2 \% \mathrm{~B}$ eluent, $6.0 \mathrm{~min} 25 \%$ B eluent, 10.0 min 50\% B eluent, $14.0 \mathrm{~min}$ 95\% B eluent, $17.0 \mathrm{~min} 95 \% \mathrm{~B}$, and $17.5 \mathrm{~min} 2 \% \mathrm{~B}$ eluent. The column temperature was thermostated at $25^{\circ} \mathrm{C}$. The flow rate was $0.4 \mathrm{~mL} / \mathrm{min}$, and the injection volume was $2.0 \mu \mathrm{L}$ (Cittan and Çelik, 2018).

The tandem mass spectrometer was coupled to the LC system using an ESI source. The electrospray source of the MS was operated in a negative and positive ionization mode, and the data acquisition was conducted in multiple reaction monitoring (MRM). The ESI source interface conditions were set: capillary voltage was $-3.5 \mathrm{kV}$, gas temperature was $300^{\circ} \mathrm{C}$, and gas flow was $11 \mathrm{~L} \mathrm{~min}^{-1}$. The nebulizer pressure was $40 \mathrm{psi}$. Analytical characters are given in Table $\mathbf{1}$.

\section{Antioxidant Activity}

Antioxidant activities of Sideritis perfoliata extracts were investigated by using several assays: total antioxidant capacity (by phosphomolybdenum and $\beta$-carotene-linoleic acid), ferrous ion chelating, reducing power [cupric ion reducing (CUPRAC), ferric reducing antioxidant power (FRAP), and potassium ferricyanide], and free radical scavenging [on 1,1-diphenyl-2picrylhydrazyl (DPPH') radical, 2,2-azino-bis (3ethylbenzothiazloine-6-sulphonic acid) radical cation $\left(\mathrm{ABTS}^{+}\right)$, superoxide anion $\left(\mathrm{O}_{2}{ }^{--}\right)$radical, and nitric oxide ( $\mathrm{NO}$ ) radical]. All of the analyses were carried out by using the experimental conditions reported by Zengin et al. (2015).

Total antioxidant activity by $\beta$-carotene-linoleic acid method is determined by measuring the inhibition of the conjugated diene hydroperoxides arising from linoleic acid oxidation. A stock solution of $\beta$-carotene-linoleic acid mixture was prepared: $0.5 \mathrm{mg} \beta$-carotene was dissolved in chloroform ( $1 \mathrm{~mL}$, HPLC grade). $25 \mu \mathrm{L}$ linoleic acid and $200 \mathrm{mg}$ Tween 40 was added. Chloroform was completely evaporated using a vacuum evaporator. Then $100 \mathrm{~mL}$ of oxygenated distilled water was added with vigorous shaking; $1.5 \mathrm{~mL}$ of this reaction mixture was dispersed to test tubes, sample solutions $(0.50 \mathrm{~mL}, 2 \mathrm{mg} / \mathrm{mL})$ were added, and the emulsion system was incubated for up to $2 \mathrm{~h}$ at $50^{\circ} \mathrm{C}$. The same procedure was repeated with the standards and a blank. After this incubation period, the sample absorbance was read at $490 \mathrm{~nm}$. Measurement of absorbance was continued until the color of $\beta$-carotene disappeared.

For total antioxidant activity by phosphomolybdenum method, the sample solution $(0.3 \mathrm{~mL})$ was combined with $3 \mathrm{~mL}$ of reagent solution (0.6 M sulfuric acid (96\%), $28 \mathrm{mM}$ sodium phosphate, and $4 \mathrm{mM}$ ammonium molybdate). The sample absorbance was read at $695 \mathrm{~nm}$ after $90 \mathrm{~min}$ incubation at $95^{\circ} \mathrm{C}$. The total antioxidant capacity was expressed as equivalents of ascorbic acid.

For ferrous ion chelating activity, the sample solution $(2 \mathrm{~mL})$ was added to $\mathrm{FeCl}_{2}$ solution $(0.05 \mathrm{~mL}, 2 \mathrm{mM})$. The reaction was initiated by the addition of $5 \mathrm{mM}$ ferrozine $(1 \mathrm{mM}, 0.2 \mathrm{~mL})$. Similarly, a blank was prepared by adding the sample solution $(2 \mathrm{~mL})$ to $\mathrm{FeCl}_{2}$ solution $(0.05 \mathrm{~mL}, 2 \mathrm{mM})$ and water $(0.2 \mathrm{~mL})$ without ferrozine. Then, the sample and blank absorbances were read at $562 \mathrm{~nm}$ after $10 \mathrm{~min}$ incubation at room temperature. The absorbance of the blank was subtracted from that of the sample. Ferrous ion chelating activity was expressed as equivalents of EDTA (ethylenediaminetetraacetic acid disodium salt).

For CUPRAC reducing power, the sample solution $(0.5 \mathrm{~mL})$ was added to a premixed reaction mixture containing $\mathrm{CuCl}_{2}$ $(1 \mathrm{~mL}, 10 \mathrm{mM})$, neocuproine $(1 \mathrm{~mL}, 7.5 \mathrm{mM})$, and $\mathrm{NH} 4 \mathrm{Ac}$ buffer ( $1 \mathrm{~mL}, 1 \mathrm{M}, \mathrm{pH} 7.0)$. Similarly, a blank was prepared by adding the sample solution $(0.5 \mathrm{~mL})$ to the premixed reaction mixture $(3 \mathrm{~mL})$ without $\mathrm{CuCl}_{2}$. Then, the sample and blank absorbances were read at $450 \mathrm{~nm}$ after a $30 \mathrm{~min}$ incubation at room temperature. The absorbance of the blank was subtracted from that of the sample. CUPRAC activity was expressed as equivalents of trolox.

For FRAP reducing power, the sample solution $(0.1 \mathrm{~mL})$ was added to premixed a FRAP reagent $(2 \mathrm{~mL})$ containing acetate buffer (0.3 M, pH 3.6), 2,4,6-Tris(2-pyridyl)-S-triazine (TPTZ) $(10 \mathrm{mM})$ in $40 \mathrm{mM} \mathrm{HCl}$, and ferric chloride $(20 \mathrm{mM})$ in a ratio of 10:1:1 (v/v/v). Then, the sample absorbance was read at $593 \mathrm{~nm}$ 
TABLE 1 | ESI-MS/MS Parameters and analytical characteristics for the Analysis of Target Analytes by MRM Negative and Positive lonization Mode.

\begin{tabular}{|c|c|c|c|c|c|c|c|c|}
\hline Target compounds & Rt (min) & Precursor ion & MRM1 (CE, V) & MRM2 (CE, V) & Linear equation & $\mathbf{R}^{2}$ & LOD $(\mu \mathrm{g} / \mathrm{L})$ & LOQ $(\mu \mathrm{g} / \mathrm{L})$ \\
\hline \multicolumn{9}{|l|}{ Compounds analyzed by NI mode } \\
\hline Gallic acid & 8.891 & $168.9[\mathrm{M}-\mathrm{H}]-$ & $125.0(10)$ & - & $y=4.82 x-26.48$ & 0.9988 & 1.46 & 4.88 \\
\hline Protocatechuic acid & 10.818 & $152.9[\mathrm{M}-\mathrm{H}]-$ & $108.9(12)$ & - & $y=5.65 x-9.99$ & 0.9990 & 1.17 & 3.88 \\
\hline 3,4-Dihydroxyphenylacetic acid & 11.224 & $167.0[\mathrm{M}-\mathrm{H}]-$ & $123.0(2)$ & - & $y=5.13 x-12.39$ & 0.9990 & 1.35 & 4.51 \\
\hline$(+)$-Catechin & 11.369 & $289.0[\mathrm{M}-\mathrm{H}]-$ & $245.0(6)$ & $202.9(12)$ & $y=1.45 x+1.95$ & 0.9974 & 3.96 & 13.20 \\
\hline Pyrocatechol & 11.506 & $109.0[\mathrm{M}-\mathrm{H}]-$ & $90.6(18)$ & $52.9(16)$ & $y=0.11 x-0.52$ & 0.9916 & 9.62 & 32.08 \\
\hline 2,5-Dihydroxybenzoic acid & 12.412 & $152.9[\mathrm{M}-\mathrm{H}]-$ & $109.0(10)$ & - & $y=3.79 x-14.12$ & 0.9980 & 2.12 & 7.08 \\
\hline 4-Hydroxybenzoic acid & 12.439 & $136.9[\mathrm{M}-\mathrm{H}]-$ & $93.1(14)$ & - & $y=7.62 x+22.79$ & 0.9996 & 1.72 & 5.72 \\
\hline Caffeic acid & 12.841 & $179.0[\mathrm{M}-\mathrm{H}]-$ & $135.0(12)$ & - & $y=11.09 x+16.73$ & 0.9997 & 3.15 & 10.50 \\
\hline Vanillic acid & 12.843 & $166.9[\mathrm{M}-\mathrm{H}]-$ & $151.8(10)$ & $122.6(6)$ & $y=0.49 x-1.61$ & 0.9968 & 2.56 & 8.54 \\
\hline Syringic acid & 12.963 & 196.9 [M - H]- & $181.9(8)$ & $152.8(6)$ & $y=0.74 x-1.54$ & 0.9975 & 3.75 & 12.50 \\
\hline 3-Hydroxybenzoic acid & 13.259 & $137.0[\mathrm{M}-\mathrm{H}]-$ & $93.0(6)$ & - & $y=3.69 x-12.29$ & 0.9991 & 1.86 & 6.20 \\
\hline Vanillin & 13.397 & $151.0[\mathrm{M}-\mathrm{H}]-$ & $136.0(10)$ & - & $y=2.02 x+135.49$ & 0.9926 & 15.23 & 50.77 \\
\hline Verbascoside & 13.589 & $623.0[\mathrm{M}-\mathrm{H}]-$ & $461.0(26)$ & $160.8(36)$ & $y=8.59 x-28.05$ & 0.9988 & 0.82 & 2.75 \\
\hline Taxifolin & 13.909 & $303.0[\mathrm{M}-\mathrm{H}]-$ & $285.1(2)$ & $125.0(14)$ & $y=12.32 x+9.98$ & 0.9993 & 1.82 & 6.05 \\
\hline Sinapic acid & 13.992 & $222.9[\mathrm{M}-\mathrm{H}]-$ & $207.9(6)$ & $163.8(6)$ & $y=2.09 x-6.79$ & 0.9974 & 2.64 & 8.78 \\
\hline p-Coumaric acid & 14.022 & $162.9[\mathrm{M}-\mathrm{H}]-$ & $119.0(12)$ & - & $y=17.51 x+53.73$ & 0.9997 & 1.93 & 6.44 \\
\hline Ferulic acid & 14.120 & $193.0[\mathrm{M}-\mathrm{H}]-$ & $177.8(8)$ & $134.0(12)$ & $y=3.32 x-4.30$ & 0.9992 & 1.43 & 4.76 \\
\hline Luteolin 7-glucoside & 14.266 & $447.1[\mathrm{M}-\mathrm{H}]-$ & $285.0(24)$ & - & $y=45.25 x+156.48$ & 0.9996 & 0.45 & 1.51 \\
\hline Rosmarinic acid & 14.600 & $359.0[\mathrm{M}-\mathrm{H}]-$ & $196.9(10)$ & $160.9(10)$ & $y=9.82 x-17.98$ & 0.9989 & 0.57 & 1.89 \\
\hline 2-Hydroxycinnamic acid & 15.031 & $162.9[\mathrm{M}-\mathrm{H}]-$ & $119.1(10)$ & - & $y=16.72 x-26.94$ & 0.9996 & 0.61 & 2.03 \\
\hline Pinoresinol & 15.118 & $357.0[\mathrm{M}-\mathrm{H}]-$ & $151.0(12)$ & $135.7(34)$ & $y=0.80 x-2.69$ & 0.9966 & 3.94 & 13.12 \\
\hline Eriodictyol & 15.247 & $287.0[\mathrm{M}-\mathrm{H}]-$ & $151.0(4)$ & $134.9(22)$ & $y=14.24 x-0.50$ & 0.9998 & 0.80 & 2.68 \\
\hline Quercetin & 15.668 & $301.0[\mathrm{M}-\mathrm{H}]-$ & $178.6(10)$ & $151.0(16)$ & $y=14.68 x-18.25$ & 0.9997 & 1.23 & 4.10 \\
\hline Kaempferol & 16.236 & $285.0[\mathrm{M}-\mathrm{H}]-$ & $242.8(16)$ & $229.1(18)$ & $y=0.82 x-3.06$ & 0.9959 & 3.30 & 10.99 \\
\hline \multicolumn{9}{|l|}{ Compounds analyzed by PI mode } \\
\hline Chlorogenic acid & 11.802 & $355.0[\mathrm{M}+\mathrm{H}]+$ & $163.0(10)$ & - & $y=12.14 x+32.34$ & 0.9995 & 0.55 & 1.82 \\
\hline (-)-Epicatechin & 12.458 & $291.0[\mathrm{M}+\mathrm{H}]+$ & $139.1(12)$ & $122.9(36)$ & $y=9.11 x-9.99$ & 0.9971 & 1.85 & 6.18 \\
\hline Hesperidin & 14.412 & $611.1[\mathrm{M}+\mathrm{H}]+$ & $449.2(4)$ & $303.0(20)$ & $y=5.98 x+0.42$ & 0.9993 & 1.73 & 5.77 \\
\hline Hyperoside & 14.506 & $465.1[\mathrm{M}+\mathrm{H}]+$ & $303.1(8)$ & - & $y=16.32 x-1.26$ & 0.9998 & 0.99 & 3.31 \\
\hline Apigenin 7-glucoside & 14.781 & $433.1[\mathrm{M}+\mathrm{H}]+$ & $271.0(18)$ & - & $y=21.33 x-31.69$ & 0.9983 & 0.41 & 1.35 \\
\hline Luteolin & 15.923 & $287.0[\mathrm{M}+\mathrm{H}]+$ & $153.1(34)$ & $135.1(36)$ & $y=8.96 x+26.80$ & 0.9992 & 1.34 & 4.46 \\
\hline Apigenin & 16.382 & $271.0[\mathrm{M}+\mathrm{H}]+$ & $153.0(34)$ & $119.1(36)$ & $y=11.29 x+38.05$ & 0.9987 & 0.96 & 3.20 \\
\hline
\end{tabular}

$R_{t}$, retention time; NI, negative ion; and Pl, positive ion.

after 30 min of incubation at room temperature. FRAP activity was expressed as equivalents of trolox.

For potassium ferricyanide reducing power, the sample solution $(0.5 \mathrm{~mL})$ was mixed with a phosphate buffer $(0.5 \mathrm{~mL}$, $0.2 \mathrm{M}, \mathrm{pH} 6.6)$ and potassium ferricyanide $(0.5 \mathrm{~mL}, 1 \%)$, and the mixture was incubated at $50^{\circ} \mathrm{C}$ for $20 \mathrm{~min}$. Then, trichloroacetic acid $(0.5 \mathrm{~mL}, 10 \%)$, deionized water $(2.5 \mathrm{~mL})$, and ferric chloride $(0.5 \mathrm{~mL}, 0.1 \%)$ were added to this mixture. Finally, the sample absorbance was read at $700 \mathrm{~nm}$. Iron (III) to iron (II) reduction activity was expressed as equivalents of trolox.

For 2,2-azino-bis (3-ethylbenzothiazloine-6-sulfonic acid) (ABTS) radical cation scavenging activity, briefly, the $\mathrm{ABTS}^{+}$ radical cation was produced directly by reacting $7 \mathrm{mM}$ ABTS solution with $2.45 \mathrm{mM}$ potassium persulfate and allowing the mixture to stand for $12-16$ hours in dark at the room temperature. Prior to beginning the assay, the ABTS solution was diluted with methanol to an absorbance of $0.700 \pm 0.02$ at $734 \mathrm{~nm}$. The sample solution $(1 \mathrm{~mL})$ was added to ABTS solution $(2 \mathrm{~mL})$ and mixed. The sample absorbance was read at $734 \mathrm{~nm}$ after $30 \mathrm{~min}$ of incubation at room temperature. The ABTS radical cation scavenging activity was expressed as equivalents of trolox.

For superoxide anion radical scavenging activity, the sample solution $(0.25 \mathrm{~mL})$ was added to reaction mixture containing riboflavin $(0.1 \mathrm{~mL}, 0.1 \mathrm{mg} / \mathrm{mL})$, EDTA $(0.1 \mathrm{~mL}, 12 \mathrm{mM})$, NBT (0.05 mL, $1 \mathrm{mg} / \mathrm{mL})$, phosphate buffer ( $1 \mathrm{~mL}, 50 \mathrm{mM}, \mathrm{pH} 7.8)$, and 1-butanol $(0.5 \mathrm{~mL})$. The reaction mixture was illuminated for $10 \mathrm{~min}$ at room temperature and the sample absorbance was read at $560 \mathrm{~nm}$. The unilluminated reaction mixture was used as a blank. The absorbance of the blank was subtracted from that of the sample, and superoxide radical scavenging activity was expressed as equivalents of trolox.

For nitric oxide (.NO) radical scavenging activity, the sample solution $(0.5 \mathrm{~mL})$ was mixed with sodium nitroprusside $(0.5 \mathrm{~mL}$, $5 \mathrm{mM})$ in phosphate buffer $(0.2 \mathrm{M}, \mathrm{pH} 7.4)$ and incubated for 150 min at room temperature. Similarly, a blank was prepared by adding sample solution $(0.5 \mathrm{~mL})$ to a phosphate buffer $(0.5 \mathrm{~mL})$. Diluted Griess reagent ( $1 \mathrm{~mL}, 1: 1)$ was added to the incubated sample and allowed to stand for $30 \mathrm{~min}$. The sample and blank absorbances were read at $548 \mathrm{~nm}$. The absorbance of the blank was subtracted from that of the sample, and the nitric oxide radical scavenging activity was expressed as equivalents of trolox.

\section{Enzyme Inhibitory Activity}

The enzymes inhibitory activities (acetylcholinesterase (AChE), butyrylcholinesterase (BChE), tyrosinase, $\alpha$-glucosidase, and $\alpha$ amylase) were evaluated by using the methods reported elsewhere (Sarikurkcu et al., 2015). 
Cholinesterase (ChE) inhibitory activity was measured using Ellman's method. The sample solution $(50 \mu \mathrm{L})$ was mixed with DTNB $(0.3 \mathrm{mM}, 125 \mu \mathrm{L})$ and AChE (or BuChE, 0.026 unit/mL) solution $(25 \mu \mathrm{L})$ in a Tris- $\mathrm{HCl}$ buffer $(50 \mathrm{mM}, \mathrm{pH} 8.0)$ in a $96-$ well microplate and incubated for $15 \mathrm{~min}$ at $25^{\circ} \mathrm{C}$. The reaction was then initiated with the addition of acetylthiocholine iodide (ATCI) or butyrylthiocholine chloride (BTCl) $(1.5 \mathrm{mM}, 25 \mu \mathrm{L})$. Similarly, a blank was prepared by adding sample solution to all reaction reagents without enzyme (AChE or BuChE) solution. The sample and blank absorbances were read at $405 \mathrm{~nm}$ after a 10 min incubation at $25^{\circ} \mathrm{C}$. The absorbance of the blank was subtracted from that of the sample and the cholinesterase inhibitory activity was expressed as equivalents of galantamine. The values of the calibration curves: for AChE, absorbance = 2.104[ $\mu \mathrm{g}$ galantamine] - $0.0033\left(\mathrm{R}^{2}: 0.9992\right)$; for $\mathrm{BChE}$, absorbance $=1.965[\mu \mathrm{g}$ galantamine $]+0.0012\left(\mathrm{R}^{2}: 0.9999\right)$

Tyrosinase inhibitory activity was measured using the modified dopachrome method with L-DOPA as substrate. The sample solution $(25 \mu \mathrm{L})$ was mixed with tyrosinase solution (200 unit/mL, $40 \mu \mathrm{L})$ and phosphate buffer $(100 \mu \mathrm{L}, \mathrm{pH} 6.8)$ in a 96well microplate and incubated for $15 \mathrm{~min}$ at $25^{\circ} \mathrm{C}$. The reaction was then initiated with the addition of L-DOPA $(10 \mathrm{mM}, 40 \mu \mathrm{L})$. Similarly, a blank was prepared by adding sample solution to all reaction reagents without enzyme (tyrosinase) solution. The sample and blank absorbances were read at $492 \mathrm{~nm}$ after a 10 min incubation at $25^{\circ} \mathrm{C}$. The absorbance of the blank was subtracted from that of the sample, and the tyrosinase inhibitory activity was expressed as equivalents of kojic acid. The value of the calibration curve: absorbance $=1.5235[\mathrm{mg}$ kojic acid $]+$ $0.0055\left(\mathrm{R}^{2}: 0.9981\right)$.

$\alpha$-Amylase inhibitory activity was performed using CarawaySomogyi iodine/potassium iodide (IKI) method. The sample solution $(25 \mu \mathrm{L})$ was mixed with $\alpha$-amylase solution $(50 \mu \mathrm{L})$ in a phosphate buffer ( $\mathrm{pH} 6.9$ with $6 \mathrm{mM}$ sodium chloride) in a 96-well microplate and incubated for $10 \mathrm{~min}$ at $37^{\circ} \mathrm{C}$. After preincubation, the reaction was initiated with the addition of starch solution $(50 \mu \mathrm{L}, 0.05 \%)$. Similarly, a blank was prepared by adding sample solution to all reaction reagents without an enzyme ( $\alpha$-amylase) solution. The reaction mixture was incubated $10 \mathrm{~min}$ at $37^{\circ} \mathrm{C}$. The reaction was then stopped with the addition of $\mathrm{HCl}(25 \mu \mathrm{L}, 1 \mathrm{M})$. This was followed by addition of the iodine-potassium iodide solution $(100 \mu \mathrm{L})$. The sample and blank absorbances were read at $630 \mathrm{~nm}$. The absorbance of the blank was subtracted from that of the sample and the $\alpha$ amylase inhibitory activity was expressed as equivalents of acarbose. The value of the calibration curve: absorbance = $2.9996[\mathrm{mg}$ acarbose $]+0.006\left(\mathrm{R}^{2}: 0.9952\right)$

For $\alpha$-glucosidase inhibitory activity, the sample solution (50 $\mu \mathrm{L})$ was mixed with glutathione $(1 \mathrm{mg} / \mathrm{mL}, 50 \mu \mathrm{L}), \alpha$-glucosidase solution $(0.2 \mathrm{unit} / \mathrm{mL}, 50 \mu \mathrm{L})$ in a phosphate buffer $(\mathrm{pH}$ 6.8) and PNPG $(10 \mathrm{mM}, 50 \mu \mathrm{L})$ in a 96-well microplate and incubated for $15 \mathrm{~min}$ at $37^{\circ} \mathrm{C}$. Similarly, a blank was prepared by adding sample solution to all reaction reagents without enzyme ( $\alpha$-glucosidase) solution. The reaction was then stopped with the addition of sodium carbonate $(50 \mu \mathrm{L}, 0.2 \mathrm{M})$. The sample and blank absorbances were read at $400 \mathrm{~nm}$. The absorbance of the blank was subtracted from that of the sample and the $\alpha$-glucosidase inhibitory activity was expressed as equivalents of acarbose. The value of the calibration curve: absorbance $=8.704[\mathrm{mg}$ acarbose $]+$ $0.0157\left(R^{2}:\right.$ 0.9961). In Supplementary Material, Figure S1-S5 were reported the calibration curves used for enzyme inhibitory activity.

\section{Statistical Analysis}

All of the assays were carried out in triplicate. Results obtained from all the assays were presented as mean and standard deviation values (mean \pm SD). ANOVA (one-way analysis of variance) and Tukey's honestly significant difference post hoc test with $\alpha=0.05$ (SPSS v. 22.0) were used to determine the differences between the assays. The Pearson linear correlation was used to evaluate the association between the results.

\section{RESULTS AND DISCUSSION}

\section{Determination of the Total Phenolic, Flavonoid, and Condensed Tannin Content and Quantitative LC-ESI-MS/MS Analysis}

In order to obtain a possible correlation between biological activities and bioactive compounds present in the extracts, it is necessary to evaluate the total phenolic, flavonoid, and condensed tannin content. This information, even if not completely useful for the plant extract characterization, allows us to better highlight that some of the biological activities could be related not only to the single compounds but also to the phytocomplex. The results are presented in Table 2 .

The spectrophotometric assays used herein (Zengin et al., 2014) allowed us to spot that water extracts were richest in terms of phenolics and condensed tannins (52.18 mg GAEs/g extract and $10.76 \mathrm{mg} \mathrm{CEs} / \mathrm{g}$ extract, respectively), while methanol extracts were the richest in terms of flavonoids (40.90 mg QEs/ g extract). Ethyl acetate extracts showed the lowest quantities for phenolics, flavonoids, and condensed tannins.

The same trend could also be observed when a deep investigation was carried out using a more complex instrument configuration. Using LC-ESI-MS/MS instrument configuration it is possible to obtain, for the considered analytes, the chemical profiles for the tested extracts, and Figure 1 displays a chromatogram showing the resolution of the chemical standards

TABLE 2 | Total phenolics, flavonoids, and condensed tannins of S. perfoliata extracts. ${ }^{\times}$

\begin{tabular}{lccc}
\hline Samples & $\begin{array}{c}\text { Total phenolics } \\
\text { (mg GAEs/g } \\
\text { extract) }\end{array}$ & $\begin{array}{c}\text { Total flavonoids } \\
\text { (mg QEs/g } \\
\text { extract) }\end{array}$ & $\begin{array}{c}\text { Total condensed } \\
\text { tannins } \\
\text { (mg CEs/g extract) }\end{array}$ \\
\hline Ethyl & $36.68 \pm 0.38^{\mathrm{c}}$ & $21.96 \pm 0.25^{\mathrm{c}}$ & $7.41 \pm 0.04^{\mathrm{b}}$ \\
acetate & $41.64 \pm 0.99^{\mathrm{b}}$ & $40.90 \pm 1.80^{\mathrm{a}}$ & $10.65 \pm 0.28^{\mathrm{a}}$ \\
Methanol & $52.18 \pm 0.75^{\mathrm{a}}$ & $29.13 \pm 0.26^{\mathrm{b}}$ & $10.76 \pm 0.05^{\mathrm{a}}$ \\
Water &
\end{tabular}

${ }^{x}$ Different subscripts in the same column indicate significant difference (by ANOVA, $p<0.05)$. GAEs, QEs, and CEs, gallic acid, quercetin, and catechin equivalents, respectively. 

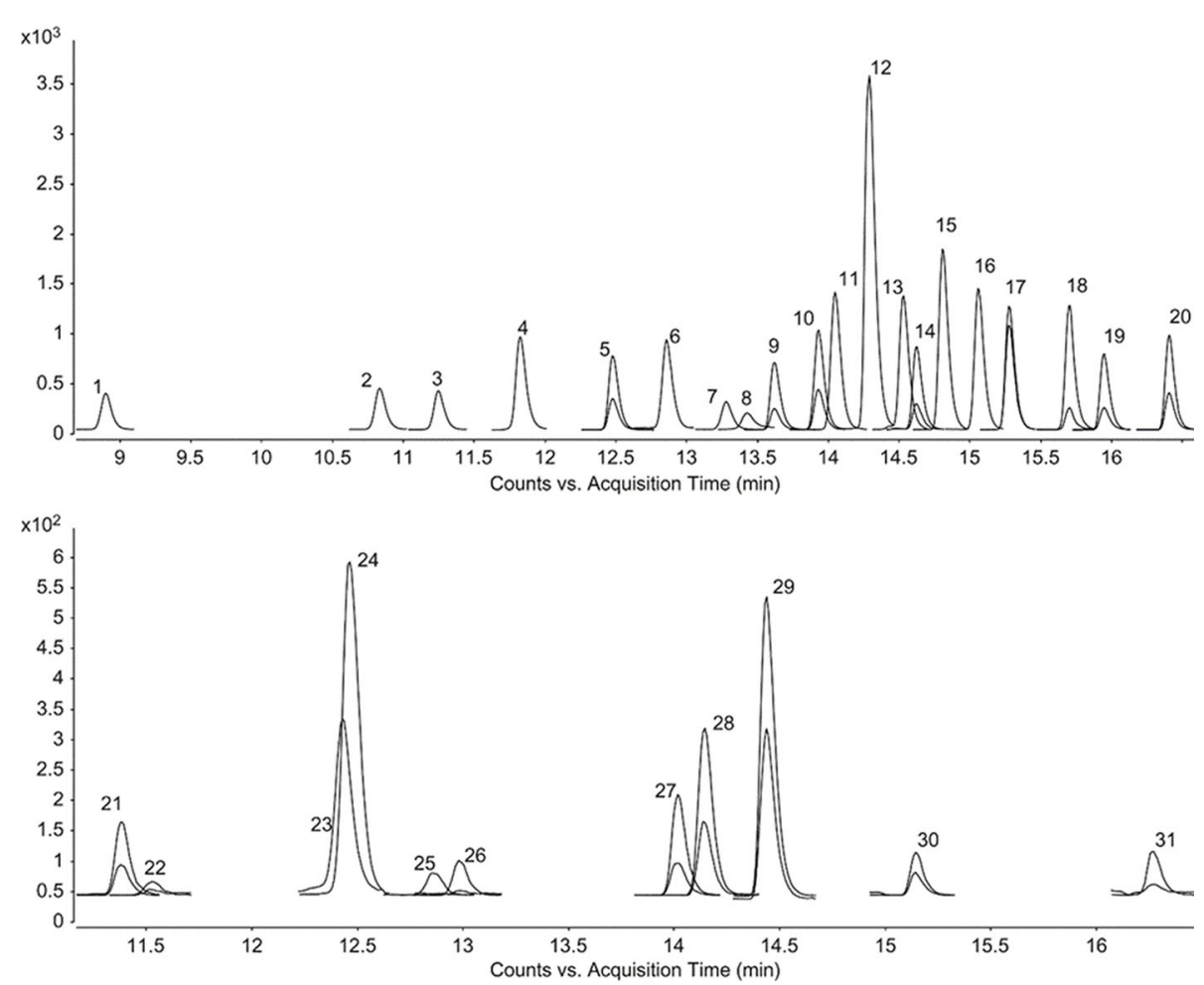

FIGURE 1 | LC-ESI-MS/MS MRM chromatograms of phenolic compounds. 1-31 represent the chromatograms of gallic acid, protocatechuic acid, 3,4dihydroxyphenylacetic acid, chlorogenic acid, (-)-epicatechin, caffeic acid, 3-hydroxybenzoic acid, vanillin, verbascoside, taxifolin, p-coumaric acid, luteolin 7glucoside, hyperoside, rosmarinic acid, apigenin 7-glucoside, 2-hydroxycinnamic acid, eriodictyol, quercetin, luteolin, apigenin, (+)-catechin, pyrocatechol, 2,5dihydroxybenzoic acid, 4-hydroxybenzoic acid, vanillic acid, syringic acid, sinapic acid, ferulic acid, hesperidin, pinoresinol, and kaempferol, respectively. The phenolic concentrations are $400 \mu \mathrm{L} \mathrm{L}^{-1}$.

considered in this study (Cittan and Çelik, 2018). The results are presented in Table 3.

In Table 3, the amounts (expressed as $\mu \mathrm{g} / \mathrm{g}$ dry extract) show that water extracts were richest with respect to methanol and ethyl acetate extracts. Figure $\mathbf{2}$ shows the most abundant compounds quantified in the LC-ESI-MS/MS analyses.

These analyses highlighted that Sideritis perfoliata contains mainly verbascoside, chlorogenic acid, and apigenin 7-glucoside (50951.10, 24933.41, and $1437.53 \mu \mathrm{g} / \mathrm{g}$ dry extract, respectively). Interestingly, the methanol extract showed a more complete phytochemical pattern in comparison with the other extracts, even if the values were lower as a total amount $(39557.33 \mu \mathrm{g} / \mathrm{g}$ methanol dry extract against $78037.37 \mu \mathrm{g} / \mathrm{g}$ water dry extract). Verbascoside represents $65.3 \%$ of the total amount for the water extract, $73.4 \%$ for methanol extract, and $87 \%$ of the ethyl acetate extract. These results are in accordance with the previous works reported in literature (Küpeli et al., 2007; Petreska et al., 2011).

Chlorogenic acid is the second most abundant compound present in all three extracts. This compound was confirmed also in Sideritis raeseri (Samanidou et al., 2012). In the same work, apigenin was also found after aglycones hydrolysis at $1.2 \mu \mathrm{g} / \mathrm{g}$ amount.

Furthermore, information on gallic acid, (-)-epicatechin, syringic acid, $p$-coumaric acid, ferulic acid, and luteolin 7- glucoside presence are available in the works of Proestos and Komaitis (2013). This work confirmed the presence of these compounds in the Sideritis cretica extracts obtained by extraction with $62.5 \%$ aqueous methanol.

To the best of our knowledge, no papers reports the presence of protocatecheuic acid, 4-hydroxybenzoic acid, vanillic acid, and caffeic acid reported herein in all the three extracts.

\section{Biological Activities}

In order to evaluate the biological activities, the different Sideritis perfoliata extracts were submitted to biological assays: total antioxidant (by phosphomolybdenum and $\beta$-carotene-linoleic acid), ferrous ion chelating, reducing power [cupric ion reducing (CUPRAC), ferric reducing antioxidant power (FRAP), and potassium ferricyanide], and free radical scavenging [on 1,1diphenyl-2-picrylhydrazyl (DPPH) radical, 2,2-azino-bis (3ethylbenzothiazloine-6-sulphonic acid) radical cation $\left(\mathrm{ABTS}^{+}\right)$, superoxide anion $\left(\mathrm{O}_{2}^{--}\right)$radical, and nitric oxide ( $\left.\mathrm{NO}\right)$ radical]. The results are presented in Table 4.

Due to the presence of different phytochemicals and related to their highest amounts in the water extract, the biological activities can be ordered as follow: water $>$ methanol $>$ ethyl acetate. Only for $\beta$-carotene bleaching assay, the order was water $>$ ethyl acetate $>$ methanol. This could be related to the 
TABLE 3 | Amounts ( $\mu \mathrm{g} / \mathrm{g}$ extract) of selected phytochemicals in the tested extracts. $^{\times}$

\begin{tabular}{|c|c|c|c|c|}
\hline Class & Compounds & $\begin{array}{c}\text { Ethyl } \\
\text { acetate }\end{array}$ & Methanol & Water \\
\hline \multirow[t]{7}{*}{$\begin{array}{l}\text { Hydroxzbenzoic } \\
\text { acids }\end{array}$} & Gallic acid & $\begin{array}{l}0.54 \pm \\
0.03^{b}\end{array}$ & $\begin{array}{c}11.26 \pm \\
0.12^{\mathrm{a}}\end{array}$ & $n d^{y}$ \\
\hline & Protocatechuic acid & $\begin{array}{l}0.95 \pm \\
0.01^{c}\end{array}$ & $\begin{array}{c}54.28 \pm \\
1.58^{\mathrm{b}}\end{array}$ & $\begin{array}{c}141.83 \pm \\
0.25^{\mathrm{a}}\end{array}$ \\
\hline & $\begin{array}{l}3,4- \\
\text { Dihydroxyphenylacetic } \\
\text { acid }\end{array}$ & nd & $\begin{array}{l}1.39 \pm \\
0.08^{\mathrm{b}}\end{array}$ & $\begin{array}{c}13.11 \pm \\
0.50^{\mathrm{a}}\end{array}$ \\
\hline & $\begin{array}{l}\text { 2,5-Dihydroxybenzoic } \\
\text { acid }\end{array}$ & nd & $\begin{array}{c}4.97 \pm \\
0.05\end{array}$ & nd \\
\hline & $\begin{array}{l}\text { 4-Hydroxybenzoic } \\
\text { acid }\end{array}$ & $\begin{array}{l}1.11 \pm \\
0.03^{\mathrm{C}}\end{array}$ & $\begin{array}{c}25.74 \pm \\
0.09^{b}\end{array}$ & $\begin{array}{c}143.00 \pm \\
0.83^{a}\end{array}$ \\
\hline & Vanillic acid & $\begin{array}{c}2.15 \pm \\
0.28^{c}\end{array}$ & $\begin{array}{c}21.29 \pm \\
0.43^{b}\end{array}$ & $\begin{array}{c}59.58 \pm \\
1.38^{\mathrm{a}}\end{array}$ \\
\hline & Syringic acid & nd & $\begin{array}{c}8.12 \pm \\
0.76^{b}\end{array}$ & $\begin{array}{c}27.92 \pm \\
0.98^{a}\end{array}$ \\
\hline \multirow[t]{6}{*}{$\begin{array}{l}\text { Hydroxycinnamic } \\
\text { acids }\end{array}$} & Chlorogenic acid & $\begin{array}{c}10.98 \pm \\
0.43^{\mathrm{C}}\end{array}$ & $\begin{array}{l}9975.82 \pm \\
323.48^{b}\end{array}$ & $\begin{array}{c}24933.41 \pm \\
1028.49^{\mathrm{a}}\end{array}$ \\
\hline & Caffeic acid & $\begin{array}{c}0.53 \pm \\
0.01^{c}\end{array}$ & $\begin{array}{c}67.15 \pm \\
0.27^{\mathrm{b}}\end{array}$ & $\begin{array}{c}186.83 \pm \\
2.91^{\mathrm{a}}\end{array}$ \\
\hline & Ferulic acid & $\begin{array}{l}1.12 \pm \\
0.02^{c}\end{array}$ & $\begin{array}{c}19.29 \pm \\
0.03^{b}\end{array}$ & $\begin{array}{c}61.84 \pm \\
0.55^{\mathrm{a}}\end{array}$ \\
\hline & Rosmarinic acid & $\begin{array}{c}1.52 \pm \\
0.19\end{array}$ & nd & nd \\
\hline & Sinapic acid & nd & $\begin{array}{c}0.70 \pm \\
0.12\end{array}$ & nd \\
\hline & $p$-Coumaric acid & nd & $\begin{array}{c}14.15 \pm \\
0.19^{b}\end{array}$ & $\begin{array}{c}22.48 \pm \\
0.17^{\mathrm{a}}\end{array}$ \\
\hline \multirow[t]{6}{*}{ Flavonoids } & Luteolin 7-glucoside & nd & $\begin{array}{c}2.45 \pm \\
0.06^{b}\end{array}$ & $\begin{array}{c}6.23 \pm \\
0.27^{\mathrm{a}}\end{array}$ \\
\hline & Hesperidin & nd & $\begin{array}{c}0.82 \pm \\
0.09\end{array}$ & nd \\
\hline & Hyperoside & nd & $\begin{array}{c}2.20 \pm \\
0.25^{\mathrm{b}}\end{array}$ & $\begin{array}{c}5.12 \pm \\
0.13^{\mathrm{a}}\end{array}$ \\
\hline & Apigenin 7-glucoside & nd & $\begin{array}{c}278.44 \pm \\
14.58^{\mathrm{b}}\end{array}$ & $\begin{array}{c}1437.53 \pm \\
316.28^{\mathrm{a}}\end{array}$ \\
\hline & Apigenin & $\begin{array}{l}1.51 \pm \\
0.03^{c}\end{array}$ & $\begin{array}{c}29.64 \pm \\
0.13^{b}\end{array}$ & $\begin{array}{c}35.41 \pm \\
0.90^{\mathrm{a}}\end{array}$ \\
\hline & (-)-Epicatechin & nd & $\begin{array}{c}0.89 \pm \\
0.14\end{array}$ & nd \\
\hline \multirow[t]{2}{*}{ Others } & Verbascoside & $\begin{array}{c}136.79 \pm \\
26.83^{c}\end{array}$ & $\begin{array}{l}29033.77 \\
\pm 145.61^{\mathrm{b}}\end{array}$ & $\begin{array}{c}50951.10 \pm \\
1175.41^{\mathrm{a}}\end{array}$ \\
\hline & Pinoresinol & nd & $\begin{array}{c}4.96 \pm \\
0.29^{b}\end{array}$ & $\begin{array}{c}12.18 \pm \\
2.32^{\mathrm{a}}\end{array}$ \\
\hline
\end{tabular}

${ }^{x}$ Different subscripts in the same row indicate significant difference $(p<0.05) ;{ }^{y}$ nd, not detected. Unreported analytes respect to the method are absent (nd) in all analyzed samples. $L O D$ and $L O Q$, limit of detection and limit of quantification, respectively.

presence, in ethyl acetate extracts, of the rosmarinic acid. This fact could obviate to a lower phytochemical amounts with respect the other extracts. Additionally, the correlation of rosmarinic acid and the $\beta$-carotene bleaching activity was just reported in literature (Öztürk, 2015).

In the literature, we observed several studies on the members of Sideritis, and the species generally indicated significant antioxidant properties. In a recent paper, the cultivated S. perfoliata subsp. perfoliata was examined in terms of chemical profile and biological abilities (Chrysargyris et al., 2019). In their study, the extracts had considerable antioxidant properties (4.34-13.25 $\mathrm{mg} \mathrm{TE} / \mathrm{g}$ fresh weight in
DPPH, 2.61-6.87 $\mathrm{mg}$ TE/g fresh weight in ABTS, and 6.89$27.31 \mathrm{mg} \mathrm{TE} / \mathrm{g}$ fresh weight in FRAP). Also, the authors reported a strong correlation between total phenolic content and these antioxidant abilities. Zengin et al. (2019) reported the antioxidant abilities of $S$. ozturkii, which were $32.48-137.30 \mathrm{mg}$ TE/g extract in DPPH, 46.78-176.45 mg TE/g extract in ABTS, and 132.47-428.61 mg TE/g extract in CUPRAC. Similar to our study, the methanol and water extracts for S. ozturkii had stronger abilities than the ethyl acetate extract. This fact was also confirmed by several researchers (Zengin et al., 2014; Sagir et al., 2017; Celep et al., 2019). As can be seen in literature, several researchers reported antioxidant parameters of some Sideritis species as $\mathrm{IC}_{50}$ or $\mathrm{EC}_{50}$ values. At this point, we could not compare with these studies. Taken together, the Sideritis genus has great interest in terms of good sources of natural antioxidants to combat oxidative stress.

\section{Enzyme Inhibitory Activity}

Enzyme inhibition theory is considered one of effective therapeutic approaches to control global health problems, including Alzheimer's disease and diabetes mellitus. In this context, the inhibitory activities of tested extracts were tested against cholinesterases (AChE and BChE), $\alpha$-amylase, $\alpha$ glucosidase, and tyrosinase. The results are presented in Table 5. The inhibitory activities against all enzymes ranged according to the extraction solvents. Generally, the water extract demonstrated lower activity against all enzymes except for tyrosinase. The observed tyrosinase inhibitory ability for water extracts may be linked to higher levels of phenolics. As is consistent with this approach, a positive correlation was observed between the antityrosinase effect and total phenolics (Table 5). Similar findings were also supported by several researchers (Kim and Uyama, 2005; Taofiq et al., 2017). The ethyl acetate and methanol extracts showed similar inhibitory effects against AChE, tyrosinase, and $\alpha$-glucosidase.

Correlation coefficients between the assays are reported in Table 6. The aim of this Table is to highlight the possible correlation between the results obtained using different tests. Interestingly, this correlation could bring to a positive or negative coefficient, and in several cases these values are higher than 0.9, highlighting that the applied assays could be used independently for the determination of a specific activities.

Similar to antioxidant properties of the members of the genus Sideritis, some studies were performed on enzyme inhibitory effects of Sideritis species. Generally, the genus Sideritis exhibited significant enzyme inhibitory potentials. For example, the AChE and tyrosinase inhibitory effects of S. ozturkii extracts (Zengin et al., 2019) were higher than those of our presented results. Also, Celep et al. (2019) reported that more than $20 \%$ of S. trojana extracts had inhibitory effects on $\alpha$-amylase and $\alpha$-glucosidase. In an earlier study (Zengin et al., 2014), the inhibitory effects of $S$. galatica extracts and the ethyl acetate and methanol extracts were more active than water, which is consistent with our results. In addition to these studies, several researchers focused on enzyme inhibitory properties of some Sideritis essential oils 
<smiles>O=C(O)c1ccc(O)cc1</smiles>

4-Hydroxybenzoic acid<smiles>O=C(O)c1ccc(O)c(O)c1</smiles>

Protocatechuic acid<smiles>O=C(O)C=Cc1ccc(O)c(O)c1</smiles>

Caffeic acid<smiles>COc1cc(/C=C/C(=O)O)ccc1O</smiles>

Ferulic acid<smiles>O=C(/C=C/c1ccc(O)c(O)c1)OC1CC(O)(C(=O)O)CC(O)C1O</smiles><smiles>COc1cc(C(=O)O)ccc1O</smiles>

Vanillic acid<smiles>O=c1cc(-c2ccc(O)cc2)oc2cc(O)cc(O)c12</smiles>

Apigenin

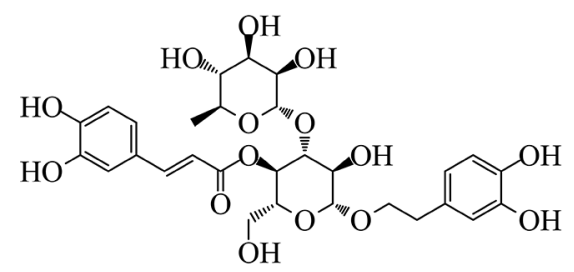

Verbascoside<smiles>O=c1cc(-c2ccc(O)cc2)oc2cc(OC3O[C@H](CO)[C@@H](O)[C@H](O)[C@H]3O)cc(O)c12</smiles>

Apigenin 7-glucoside

FIGURE 2 | Chemical structures of the major analytes quantified by LC-ESI-MS/MS method.

TABLE 4 | Radical scavenging, reducing power, ferrous ion chelating, and total antioxidant (by phosphomolybdenum and $\beta$-carotene bleaching methods) activities of $S$. perfoliata extracts. ${ }^{\times}$

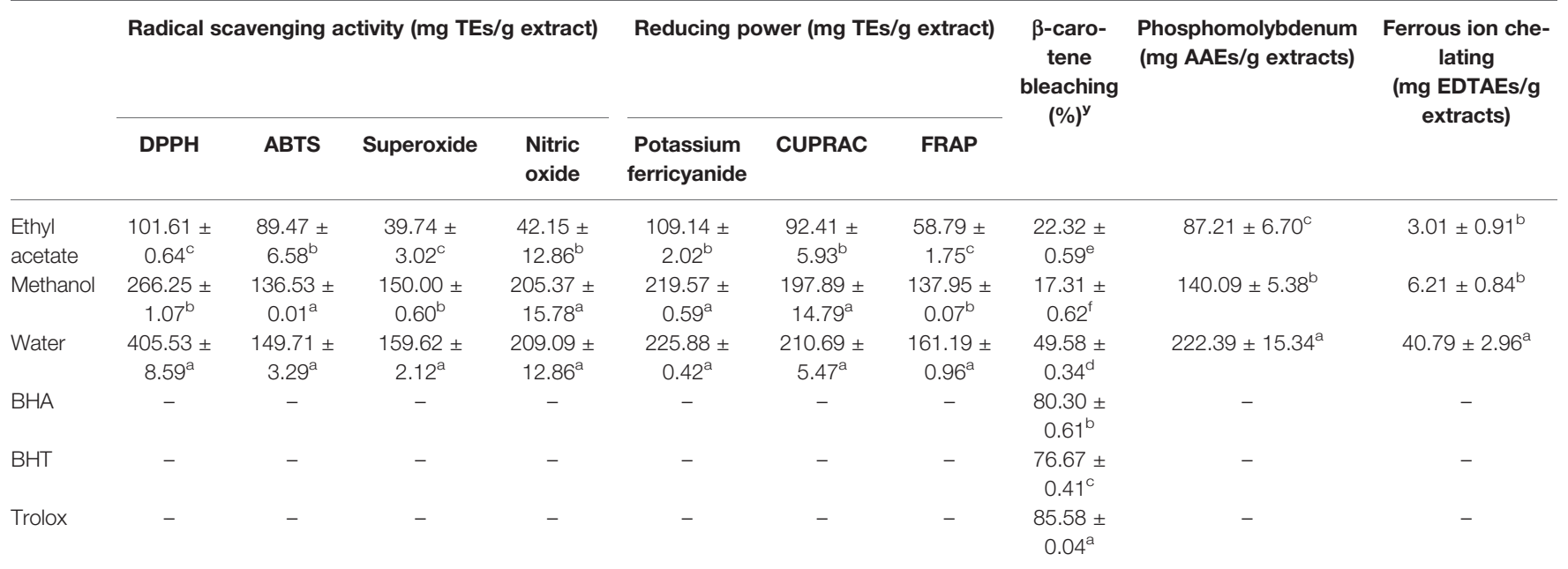

${ }^{x}$ Different subscripts in the same row indicate significant difference (by ANOVA, $\left.p<0.05\right)$. TEs, AAEs, and EDTAEs, trolox, ascorbic acid, and ethylenediaminetetraacetic acid (disodium salt) equivalents, respectively. ${ }^{y}$ Given as percentage of $\%$ inhibition of the linoleic acid at $2 \mathrm{mg} / \mathrm{ml}$ concentration.

(Zengin et al., 2016; Tadić et al., 2017; Deveci et al., 2019). Altogether, the genus Sideritis is a significant source of natural enzyme inhibitors.

\section{Conclusion}

In the present work, different biological effects for three different Sideritis perfoliata extracts as well as their chemical profiles obtained using highly hyphenated instrument configuration were reported. From the results reported herein, it was apparent that the biological activities and chemical profiles were strictly dependent on the extraction solvents system. Verbascoside, chlorogenic acid, and apigenin 7-glucoside were the major phenolic components determined in these extracts. Generally, the methanol and water extracts showed greater antioxidant 
TABLE 5 | Enzyme inhibitory activities of $S$. perfoliata extracts. ${ }^{\times}$

\begin{tabular}{|c|c|c|c|c|c|}
\hline & $\begin{array}{c}\text { AChE } \\
\text { (mg GALAEs/g extract) }{ }^{y}\end{array}$ & $\begin{array}{c}\text { BChE } \\
\text { (mg GALAEs/g extract) }{ }^{y}\end{array}$ & $\begin{array}{c}\text { Tyrosinase } \\
\text { (mg KAEs/g extract) }^{z}\end{array}$ & $\begin{array}{c}\alpha-A m y l a s e \\
\text { (mg ACEs/g extract) }^{w}\end{array}$ & $\begin{array}{c}\alpha \text {-Glucosidase } \\
\text { (mg ACEs/g extract) }^{w}\end{array}$ \\
\hline Ethyl acetate & $0.23 \pm 0.03^{\mathrm{ab}}$ & $0.53 \pm 0.01^{a}$ & $5.97 \pm 0.76^{b}$ & $36.57 \pm 1.92^{b}$ & $175.90 \pm 1.46^{a}$ \\
\hline Methanol & $0.26 \pm 0.03^{a}$ & $0.35 \pm 0.03^{b}$ & $7.80 \pm 0.01^{b}$ & $48.76 \pm 2.19^{a}$ & $169.12 \pm 4.22^{a}$ \\
\hline Water & $0.14 \pm 0.03^{b}$ & $0.09 \pm 0.01^{c}$ & $14.65 \pm 0.16^{a}$ & $33.28 \pm 0.01^{b}$ & $112.94 \pm 5.69^{b}$ \\
\hline
\end{tabular}

${ }^{x}$ Different subscripts in the same row indicate significant difference (by ANOVA, $\left.p<0.05\right)$. GALAEs, KAEs, and ACEs, galanthamine, kojic acid, and acarbose equivalents, respectively.

TABLE 6 | Correlation coefficients between the assays. ${ }^{\times}$

\begin{tabular}{|c|c|c|c|c|c|c|c|c|c|c|c|c|c|c|c|}
\hline & TACB & TAP & MCA & DPPH & ABTS & SAR & NOR & PFRP & CUPRAC & FRAP & ACIA & $\mathrm{BCIA}$ & TIA & AAIA & AGIA \\
\hline Total condensed tannins & 0.397 & 0.814 & 0.588 & 0.902 & 0.984 & $0.999^{y}$ & $0.999^{z}$ & $0.999^{z}$ & $0.998^{y}$ & 0.982 & -0.305 & -0.826 & 0.684 & 0.287 & -0.606 \\
\hline Total flavonoids & -0.280 & 0.256 & -0.063 & 0.419 & 0.643 & 0.742 & 0.776 & 0.758 & 0.724 & 0.636 & 0.373 & -0.276 & 0.062 & 0.832 & 0.041 \\
\hline Total phenolics & 0.895 & 0.997 & 0.971 & 0.968 & 0.868 & 0.792 & 0.759 & 0.777 & 0.808 & 0.873 & -0.847 & -0.995 & 0.993 & -0.397 & -0.976 \\
\hline Protocatechuic acid & 0.863 & $0.999^{z}$ & 0.953 & 0.982 & 0.899 & 0.831 & 0.800 & 0.817 & 0.845 & 0.903 & -0.810 & $-0.999^{y}$ & 0.983 & -0.336 & -0.959 \\
\hline Chlorogenic acid & 0.851 & $0.999^{z}$ & 0.945 & 0.987 & 0.909 & 0.844 & 0.814 & 0.831 & 0.858 & 0.913 & -0.795 & $-0.999^{z}$ & 0.979 & -0.313 & -0.952 \\
\hline 4-Hydroxybenzoic acid & 0.953 & 0.972 & 0.996 & 0.918 & 0.781 & 0.688 & 0.649 & 0.670 & 0.707 & 0.786 & -0.919 & -0.967 & $0.999^{y}$ & -0.534 & $-0.998^{y}$ \\
\hline Vanillic acid & 0.888 & $0.998^{y}$ & 0.967 & 0.972 & 0.876 & 0.801 & 0.769 & 0.787 & 0.817 & 0.880 & -0.839 & -0.996 & 0.991 & -0.383 & -0.972 \\
\hline Caffeic acid & 0.875 & $0.999^{y}$ & 0.960 & 0.978 & 0.888 & 0.817 & 0.786 & 0.803 & 0.832 & 0.892 & -0.824 & $-0.998^{y}$ & 0.987 & -0.358 & -0.966 \\
\hline Verbascoside & 0.733 & 0.979 & 0.865 & $0.999^{y}$ & 0.973 & 0.932 & 0.911 & 0.922 & 0.941 & 0.975 & -0.664 & -0.983 & 0.921 & -0.124 & -0.875 \\
\hline Ferulic acid & 0.905 & 0.995 & 0.976 & 0.962 & 0.857 & 0.778 & 0.744 & 0.763 & 0.795 & 0.861 & -0.859 & -0.992 & 0.996 & -0.418 & -0.981 \\
\hline Apigenin 7-glucoside & 0.947 & 0.977 & 0.994 & 0.926 & 0.794 & 0.703 & 0.664 & 0.686 & 0.722 & 0.799 & -0.911 & -0.972 & $0.999^{y}$ & -0.517 & -0.996 \\
\hline Apigenin & 0.513 & 0.883 & 0.689 & 0.951 & $0.999^{y}$ & 0.996 & 0.990 & 0.994 & $0.998^{y}$ & $0.998^{y}$ & -0.427 & -0.892 & 0.774 & 0.160 & -0.704 \\
\hline
\end{tabular}

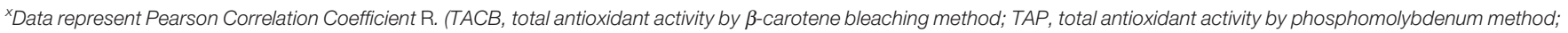
$M C A$, metal chelating activity; DPPH, DPPH radical scavenging activity; ABTS, ABTS radical scavenging activity; SAR, superoxide anion radical scavenging activity; NOR, nitric oxide radical scavenging activity; PFRP, potassium ferricyanide reducing power potential; CUPRAC, CUPRAC reducing power potential; FRAP, FRAP reducing power potential; ACIA, acetyl cholinesterase inhibition activity; BCIA, butyrylcholinesterase inhibitory activity; TIA, tyrosinase inhibitory activity; AAIA, $\alpha$-amylase inhibition activity; AGIA, $\alpha$-glucosidase inhibition activity); ${ }^{y}$ indicates $p<0.05 ;^{z}$ indicates $p<0.01$

activities respect to ethyl acetate extracts. Investigated Sideritis perfoliata showed worthy inhibitory properties with regards to key enzymes associated to Alzheimer's disease and Diabetes mellitus health diseases.

In recent years, novel and safe products have displayed great interest in the prevention and management of global health problems, including Alzheimer's disease, diabetes mellitus, and oxidative stress. In this sense, our findings could contribute significant information for scientific platforms. From the results reported herein, the investigated Sideritis perfoliata could be considered as a favorable font of natural agents for the future development of new pharmaceuticals and as a potential source of biological active compounds for the food supplements, such as nutraceuticals, functional foods or biologically-active products.

It is necessary to highlight that further experimental studies, such as in vivo models and toxicological assays, are necessary for the studied plant material. Additional information is required also to standardize and to modify the production process to an industrial scale.

\section{REFERENCES}

Barber, J. C. (2000). Evolution of endemic Sideritis (Lamiaceae) in Macaronesia: insights from a chloroplast DNA restriction site analysis. Syst. Bot. 25 (4), 633647. doi: $10.2307 / 2666725$

Boy, H. I. A., Rutilla, A. J. H., Santos, K. A., Ty, A. M. T., Alicia, I. Y., Mahboob, T., et al. (2018). Recommended medicinal plants as source of

\section{AUTHOR CONTRIBUTIONS}

BK and CS set up and carried out experiments. ML, AM, and GZ carried out the data analysis and paper writing and revision.

\section{ACKNOWLEDGMENTS}

The authors would like to thank Dr. Olcay Ceylan for her kind help in identifying the plant material used in this study. The authors also would like to thank Aysegul Polat and Zulkifl Keskin, students at the Department of Medicinal and Aromatic Plants, Atabey Vocational School, Süleyman Demirel University, Isparta-Turkey, for their kind contribution with the collection and analyzing of the plant material.

\section{SUPPLEMENTARY MATERIAL}

The Supplementary Material for this article can be found online at: https://www.frontiersin.org/articles/10.3389/fphar.2019. 01642/full\#supplementary-material

natural products: a review. Dig. Chin. Med. 1 (2), 131-142. doi: 10.1016/ S2589-3777(19)30018-7

Celep, E., Seven, M., Akyüz, S., İnan, Y., and Yesilada, E. (2019). Influence of extraction method on enzyme inhibition, phenolic profile and antioxidant capacity of Sideritis trojana Bornm. S. Afr. J. Bot. 121, 360-365. doi: 10.1016/j.sajb.2018.11.026

Charami, M. T., Lazari, D., Karioti, A., Skaltsa, H., Hadjipavlou-Litina, D., and Souleles, C. (2008). Antioxidant and antiinflammatory activities of Sideritis 
perfoliata subsp. perfoliata (Lamiaceae). Phytother. Res. 22 (4), 450-454. doi: $10.1002 /$ ptr.2333

Çelik, Í., Ersanlı, C. C., Köseoğlu, R., Akşit, H., Erenler, R., Demirtaş, I., et al. (2016). Crystal structure of 3,4a,7,7,10a-penta-methyl-3-vinyl-dodeca-hydro1H-benzo[f]chromen-9-ol isolated from Sideritis perfoliata. Acta Crystallogr. E Crystallogr. Commun. 72 (Pt 10), 1380-1382. doi: 10.1107/S2056989016013864

Chrysargyris, A., Kloukina, C., Vassiliou, R., Tomou, E. M., Skaltsa, H., and Tzortzakis, N. (2019). Cultivation strategy to improve chemical profile and anti-oxidant activity of Sideritis perfoliata L. subsp. perfoliata. Ind. Crop Prod. 140, 111694. doi: 10.1016/j.indcrop.2019.111694

Cittan, M., and Çelik, A. (2018). Development and validation of an analytical methodology based on liquid chromatography-electrospray tandem mass spectrometry for the simultaneous determination of phenolic compounds in olive leaf extract. J. Chromatogr. Sci. 56 (4), 336-343. doi: 10.1093/chromsci/ bmy003

Davis P. H. (Ed.). (1982). Flora of Turkey and the East Aegean Islands Vol. 7 (Edinburgh: University Press).

Deveci, E., Tel-Çayan, G., Usluer, Ö., and Duru, M. E. (2019). Chemical composition, antioxidant, anticholinesterase and anti-tyrosinase activities of essential oils of two Sideritis species from Turkey. Iran J. Pharm. Res. 18 (2), 903. doi: 10.22037/ijpr.2019.1100657

Di Sotto, A., Vecchiato, M., Abete, L., Toniolo, C., Giusti, A. M., Mannina, L., et al. (2018). Capsicum annuum L. var. Cornetto di Pontecorvo PDO: Polyphenolic profile and in vitro biological activities. J. Funct. Foods 40, 679-691. doi: 10.1016/j.jff.2017.11.041

González-Burgos, E., Carretero, M. E., and Gómez-Serranillos, M. P. (2011). Sideritis spp.: Uses, chemical composition and pharmacological activities-A review. J. Ethnopharmacol. 135 (2), 209-225. doi: 10.1016/j.jep.2011.03.014

Küpeli, E., Sahin, F. P., Yeşilada, E., Caliş, I., and Ezer, N. (2007). In vivo antiinflammatory and antinociceptive activity evaluation of phenolic compounds from Sideritis stricta. Z Naturforsch. C. 62 (7-8), 519-525. doi: 10.1515/znc2007-7-810

Kim, Y. J., and Uyama, H. (2005). Tyrosinase inhibitors from natural and synthetic sources: structure, inhibition mechanism and perspective for the future. Cell. Mol. Life Sci. CMLS 62 (15), 1707-1723. doi: 10.1007/s00018005-5054-y

Lall, N., Chrysargyris, A., Lambrechts, I., Fibrich, B., Blom Van Staden, A., Twilley, D., et al. (2019). Sideritis Perfoliata (Subsp. Perfoliata) nutritive value and its potential medicinal properties. Antioxidants 8 (11), 521. doi: 10.3390/antiox8110521

Lindqvist, C., and Albert, V. A. (2002). Origin of the Hawaiian endemic mints within North American Stachys (Lamiaceae). Am. J. Bot. 89 (10), 1709-1724. doi: 10.3732/ajb.89.10.1709

Locatelli, C., Melucci, D., and Locatelli, M. (2014). Toxic metals in herbal medicines. A review. Curr. Bioact. Comp. 10 (3), 181-188. doi: 10.2174/ 1573407210666140716164321

Locatelli, M., Zengin, G., Uysal, A., Carradori, S., De Luca, E., Bellagamba, G., et al. (2017). Multicomponent pattern and biological activities of seven Asphodeline taxa: Potential sources of natural-functional ingredients for bioactive formulations. J. Enz. Inhib. Med. Chem. 32 (1), 60-67. doi: 10.1080/ 14756366.2016.1235041

Loizzo, M. R., Tundis, R., Menichini, F., Saab, A. M., Statti, G. A., and Menichini, F. (2007). Cytotoxic activity of essential oils from labiatae and lauraceae families against in vitro human tumor models. Anticancer Res. 27 (5A), 3293-3299.

Loizzo, M. R., Saab, A. M., Tundis, R., Menichini, F., Bonesi, M., Piccolo, V., et al. (2008). In vitro inhibitory activities of plants used in Lebanon traditional medicine against angiotensin converting enzyme (ACE) and digestive enzymes related to diabetes. J. Ethnopharmacol. 119 (1), 109-116. doi: 10.1016/ j.jep.2008.06.003

Melucci, D., Locatelli, M., and Locatelli, C. (2013). Trace level voltammetric determination of heavy metals and total mercury in tea matrices (Camellia sinensis)doi: 10.1016/j.fct.2013.10.029. Food Chem. Toxicol. 62, 901-907. doi: 10.1016/j.fct.2013.10.029

Melucci, D., Locatelli, M., De Laurentiis, F., Zengin, G., and Locatelli, C. (2018). Herbal medicines: application of a sequential voltammetric procedure to the determination of mercury, copper, lead, cadmium and zinc at trace level. Lett. Drug Des. Discovery 15 (3), 270-280. doi: 10.2174/1570180814666170412124634
Öztürk, N. (2015). Phenolic composition and antioxidant activity of the different extracts from Thymus longicaulis C Presl. subsp. longicaulis var. longicaulis and T. longicaulis C. Presl. subsp. longicaulis var. subisophyllus growing in Turkey. Pak. J. Pharm. Sci. 28 (2), 465-472.

Petreska, J., Stefkov, G., Kulevanova, S., Alipieva, K., Bankova, V., and Stefova, M. (2011). Phenolic compounds of mountain tea from the Balkans: LC/DAD/ESI/ MSn profile and content. Nat. Prod. Commun. 6 (1), 21-30. doi: 10.1177/ 1934578X1100600107

Proestos, C., and Komaitis, M. (2013). Analysis of naturally occurring phenolic compounds in aromatic plants by RP-HPLC coupled to diode array detector (DAD) and GC-MS after Silylation. Foods 2, 90-99. doi: 10.3390/foods2010090

Sagir, Z. O., Carikci, S., Kilic, T., and Goren, A. C. (2017). Metabolic profile and biological activity of Sideritis brevibracteata PH Davis endemic to Turkey. Int. J. Food Prop. 20 (12), 2994-3005. doi: 10.1080/10942912.2016.1265981

Samanidou, V., Tsagiannidis, A., and Sarakatsianos, I. (2012). Simultaneous determination of polyphenols and major purine alkaloids in Greek Sideritis species, herbal extracts, green tea, black tea, and coffee by high-performance liquid chromatography-diode array detection. J. Sep. Sci. 35 (4), 608-615. doi: $10.1002 /$ jssc. 201100894

Sarikurkcu, C., Uren, M. C., Tepe, B., Cengiz, M., and Kocak, M. S. (2014). Phenolic content, enzyme inhibitory and antioxidative activity potentials of Phlomis nissolii and P. pungens var. pungens. Ind. Crops Prod. 62, 333-340. doi: 10.1016/j.indcrop.2014.09.002

Sarikurkcu, C., Zengin, G., Oskay, M., Uysal, S., Ceylan, R., and Aktumsek, A. (2015). Composition, antioxidant, antimicrobial and enzyme inhibition activities of two Origanum vulgare subspecies (subsp vulgare and subsp hirtum) essential oils. Ind. Crops Prod. 70, 178-184. doi: 10.1016/ j.indcrop.2015.03.030

Shen, B. (2015). A new golden age of natural products drug discovery. Cell 163 (6), 1297-1300. doi: 10.1016/j.cell.2015.11.031

Sobolev, A. P., Mannina, L., Capitani, D., Sanzò, G., Ingallina, C., Botta, B., et al. (2018). A multi-methodological approach in the study of Italian PDO "Cornetto di Pontecorvo" red sweet pepper. Food Chem. 255, 120-131. doi: 10.1016/j.foodchem.2018.02.050

Tadić, V., Jeremic, I., Dobric, S., Isakovic, A., Markovic, I., Trajkovic, V., et al. (2012). Anti-inflammatory, gastroprotective, and cytotoxic effects of Sideritis scardica extracts. Planta Med. 78 (5), 415-427. doi: 10.1055/s-0031-1298172

Tadić, V., Oliva, A., Božović, M., Cipolla, A., De Angelis, M., Vullo, V., et al. (2017). Chemical and antimicrobial analyses of Sideritis romana L. subsp. purpurea (Tal. ex Benth.) Heywood, an endemic of the Western Balkan. Molecules 22 (9), 1395. doi: 10.3390/molecules22091395

Taofiq, O., González-Paramás, A. M., Barreiro, M. F., and Ferreira, I. C. (2017). Hydroxycinnamic acids and their derivatives: Cosmeceutical significance, challenges and future perspectives, a Review. Molecules 22 (2), 1-24. doi: $10.3390 /$ molecules 22020281

Uysal, S., Zengin, G., Locatelli, M., Bahadori, M. B., Mocan, A., Bellagamba, G., et al. (2017). Cytotoxic and enzyme inhibitory potential of two Potentilla species (P. speciosa L. and P. reptans Willd.) and their chemical composition. Front. Pharmacol. 8 (290), 1-11. doi: 10.3389/fphar.2017.00290

Villar, A., Recio, M. C., Ríos, J. L., and Zafra-Polo, M. C. (1986). Antimicrobial activity of essential oils from Sideritis species. Die Pharm. 41 (4), 298-299.

Zengin, G., Sarikurkcu, C., Aktumsek, A., and Ceylan, R. (2014). Sideritis galatica Bornm.: a source of multifunctional agents for the management of oxidative damage, Alzheimer's's and diabetes mellitus. J. Funct. Food. 11, 538-547. doi: 10.1016/j.jff.2014.08.011

Zengin, G., Sarikurkcu, C., Aktumsek, A., Ceylan, R., and Ceylan, O. (2014). A comprehensive study on phytochemical characterization of Haplophyllum myrtifolium Boiss. endemic to Turkey and its inhibitory potential against key enzymes involved in Alzheimer, skin diseases and type II diabetes. Ind. Crops Prod. 53, 244-251. doi: 10.1016/j.indcrop.2013.12.043

Zengin, G., Sarikurkcu, C., Uyar, P., Aktumsek, A., Uysal, S., Kocak, M. S., et al. (2015). Crepis foetida L. subsp rhoeadifolia (Bleb.) Celak. as a source of multifunctional agents: Cytotoxic and phytochemical evaluation. J. Funct. Foods 17, 698-708. doi: 10.1016/j.jff.2015.06.041

Zengin, G., Sarıürkçü, C., Aktümsek, A., and Ceylan, R. (2016). antioxidant potential and inhibition of key enzymes linked to alzheimer's diseases and diabetes mellitus by monoterpene-rich essential oil from sideritis galatica bornm. endemic to turkey. Rec. Nat. Prod. 10 (2), 195-206. 
Zengin, G., Uğurlu, A., Baloglu, M. C., Diuzheva, A., Jekő, J., Cziáky, Z., et al. (2019). Chemical fingerprints, antioxidant, enzyme inhibitory, and cell assays of three extracts obtained from Sideritis ozturkii Aytaç \& aksoy: an endemic plant from turkey. J. Pharm. Biomed. Anal. 171, 118-125. doi: 10.1016/ j.jpba.2019.04.011

Conflict of Interest: The authors declare that the research was conducted in the absence of any commercial or financial relationships that could be construed as a potential conflict of interest.
The reviewer AU declared a shared affiliation, with no collaboration, with one of the authors, GK, to the handling editor at time of review.

Copyright $\odot 2020$ Sarikurkcu, Locatelli, Mocan, Zengin and Kirkan. This is an openaccess article distributed under the terms of the Creative Commons Attribution License (CCBY). The use, distribution or reproduction in other forums is permitted, provided the original author(s) and the copyright owner(s) are credited and that the original publication in this journal is cited, in accordance with accepted academic practice. No use, distribution or reproduction is permitted which does not comply with these terms. 